\title{
SNOWMOBILES IN SASKATCHEWAN
}

In "A new menace to wildlife" (Blue Jay, March, 1967) R. D. Symons described the "skidoo" and four years later, in March, 1971, I commented editorially on the harmful effects of the snowmobile. At that time I was concerned about such matters as noise pollution and destruction of habitat brought about by the existence of the vehicle as such. But the letter on page 70 of this issue and a recent personal experience have brought the problem of the use certain individuals make of the machine sharply into focus for me.

On the day of our 1971 Christmas bird count in the area northwest of Regina I actually observed the chase of a red fox in the deep snow of a stubble field. Two snowmobiles continuously chased the fox back and forth, successfully preventing his escape to the brush and woods of Boggy Creek. I could do nothing to stop them though they saw both my car on the road and my repeated gesticulating. Eventually the chase ended but beyond a little knoll so that I could not see what actually took place. Later, when one of the drivers (snowmobile licence \#19-454) joined me, I told him that by harassing the fox he had been breaking a law. Surprised, he made light of the affair and implied that his was the normal approach and mine a slightly humorous one.

Many areas in the world are making a positive attempt to meet the everincreasing threat of the snowmobile. In France, for instance, the snowmobile for personal use has been prohibited (Leader-Post, January 13, 1972). In the United States, many areas are restricting the use of snowmobiles in a more rigorous manner than that used in the past (Newsweek, January 24, 1972). Closer to home, the Wascana Centre Authority, which until recently had tried to live with the snowmobile and had allowed its use in parts of this rather extensive property, has banned the machine from the area. Obviously, the snowmobile is harming the very habitat the Authority is attempting to maintain and develop.

Unfortunately, the Government of Saskatchewan is apparently reluctant to face the "off-road vehicle" problem. (In this connection, do not forget the ominous fact that not only the snowmobile but also the trail bike, the dune buggy and the four-wheel-drive jeep have become a plague in the United States.) Not only are snowmobiles allowed in our provincial parks but their presence in the parks is enthusiastically encouraged. The DNR Resource Report (5:46, February 10, 1971) describes all the power toboggan trails and trailside shelters currently under construction in provincial parks at Cypress Hills, Belanger Creek, Battleford, Pike Lake, Goodspirit, Moose Mountain, Duck Mountain, Echo Valley, Blackstrap and Buffalo Pound and states that other trails are being planned. The report emphasizes that the trails will open up aesthetic areas of the parks which in the summer are inaccessible by car. There is no suggestion that use of snowmobiles in parks will be limited to the designated trails and there is no evidence that the government is more prepared to enforce its legislation against harassment of wildlife in park areas any more than it is in the environs of Boggy Creek. Admittedly, the legislation is difficult to enforce but with proper equipment it could be done. (Certainly, the fines must be very much heavier, e.g. a minimum of $\$ 1000$ instead of a maximum of $\$ 100$.)

Now, the government's recent announcement that municipalities may apply for permits to hunt foxes and coyotes from snowmobiles when there is evidence of predation and over-population of these animals also suggests that the government not only condones the killing of animals from motorized vehicles but that it had little intention in the first place of trying to enforce its legislation against the harassment of wildlife by snowmobiles.

If you are concerned, as all natural history people must be, you should write to the government demanding that it examine its policy regarding the use of snowmobiles. Send a copy of your letter to the Blue Jay editor. 